\title{
Stability of Commonly Used Antibiotic Solutions in an Elastomeric Infusion Device
}

\author{
Scott E Walker, John lazzetta, Shirley Law, and Kristof Biniecki
}

\begin{abstract}
Background: The Accufuser silicone-based elastomeric infusion device has recently been approved for the Canadian market.

Objective: To evaluate the stability of 5 antibiotics (cefazolin, ceftazidime, ceftriaxone, clindamycin, and vancomycin) in either 5\% dextrose in water (D5W) or $0.9 \%$ sodium chloride in water (NS) after storage in Accufuser disposable silicone balloon infusers.

Methods: The study drugs were reconstituted, according to the manufacturers' directions, in polyvinyl chloride minibags with either D5W or NS, at 2 different concentrations. The resulting solutions were transferred to disposable silicone balloon infusers for storage at $4^{\circ} \mathrm{C}$ or at room temperature $\left(23^{\circ} \mathrm{C}\right)$. The concentration of each drug in each solution was determined by validated stability-indicating liquid chromatographic methods after storage for 14 to 31 days.

Results: Solutions of ceftriaxone in either diluent retained more than $95.2 \%$ of the initial concentration for 2 days at room temperature and more than $91.6 \%$ of the initial concentration for 14 days at $4^{\circ} \mathrm{C}$. Solutions of cefazolin in D5W or NS retained more than $90 \%$ of the initial concentration for at least 3 days at room temperature and for at least 26 days at $4^{\circ} \mathrm{C}$. Solutions of ceftazidime in D5W or NS retained more than $90 \%$ of the initial concentration for only 1 day when stored at room temperature and for at least 4 days at $4^{\circ} \mathrm{C}$. Solutions of clindamycin or vancomycin in D5W or NS retained $90 \%$ of the initial concentration for at least 7.5 days at room temperature and at least $90 \%$ of the initial concentration for at least 27.8 days at $4^{\circ} \mathrm{C}$.

Conclusions: Previously reported expiration dates for solutions stored in elastomeric infusion devices were not based on $95 \%$ confidence intervals and were often longer than expiration dates determined from the studies reported here, which are based on 95\% confidence intervals. Comparison of the observed concentrations remaining between previously published studies and the studies reported here indicates that the Accufuser elastomeric infusion device did not adversely affect the stability of these drugs.
\end{abstract}

Key words: drug stability, cefazolin, ceftazidime, ceftriaxone, clindamycin, vancomycin

Can J Hosp Pharm 2010;63(3):212-224

\section{RÉSUMÉ}

Contexte : L'Accufuser, un perfuseur à base d'élastomère de silicone, a été approuvé récemment sur le marché canadien.

Objectif : Évaluer la stabilité de cinq antibiotiques (céfazoline, ceftazidime, ceftriaxone, clindamycine et vancomycine) préparés dans du dextrose à $5 \%$ pour injection (dextrose à $5 \%$ dans l'eau [D5E]) ou du chlorure de sodium à $0,9 \%$ pour injection (solution physiologique salée [SP]) et conservés dans des perfuseurs à ballonnet en silicone jetables.

Méthodes : Les antibiotiques ont été reconstitués conformément aux directives du fabricant dans des minisacs de polychlorure de vinyle selon deux concentrations avec du D5E ou de la SP. Les solutions ainsi reconstituées ont été transférées dans des perfuseurs à ballonnet en silicone jetables qui ont été entreposés à $4^{\circ} \mathrm{C}$ ou à la température ambiante $\left(23^{\circ} \mathrm{C}\right)$. La concentration de chaque antibiotique dans chaque solution a été déterminée à l'aide d'épreuves validées par chromatographie liquide haute performance mesurant la stabilité après une période d'entreposage de 14 à 31 jours.

Résultats : Les solutions de ceftriaxone dans l'un ou l'autre des diluants ont retenu plus de 95,2\% de leur concentration initiale pendant deux jours à la température ambiante et plus de 91,6\% de leur concentration initiale de médicament pendant 14 jours à une température de $4{ }^{\circ} \mathrm{C}$. Les solutions de céfazoline dans du D5E ou de la SP ont retenu plus de $90 \%$ de leur concentration initiale pendant une période d'au moins trois jours à la température ambiante et au moins $90 \%$ de leur concentration initiale pendant au moins 26 jours à $4{ }^{\circ} \mathrm{C}$. Les solutions de ceftazidime dans du D5E ou de la SP ont retenu plus de $90 \%$ de leur concentration initiale pendant une journée seulement lorsqu'entreposées à la température ambiante et pendant au moins quatre jours à $4{ }^{\circ} \mathrm{C}$. Les solutions de clindamycine ou de vancomycine dans du D5E ou de la SP ont retenu $90 \%$ de leur concentration initiale pendant au moins 7,5 jours à la température ambiante et au moins $90 \%$ de leur concentration initiale pendant au moins 27,8 jours à $4{ }^{\circ} \mathrm{C}$.

Conclusions : Les durées de conservation publiées antérieurement pour les solutions conservées dans des perfuseurs en élastomère n'étaient pas basées sur des intervalles de confiance à $95 \%$ et étaient souvent supérieures aux durées de conservation déterminées dans la présente étude, qui sont elles basées sur des intervalles de confiance à $95 \%$. La comparaison des concentrations restantes observées entre les études publiées antérieurement et la présente étude indique que le perfuseur Accufuser à base d'élastomère n'affecte pas la stabilité de ces antibiotiques.

Mots clés : stabilité des médicaments, céfazoline, ceftazidime, ceftriaxone, clindamycine et vancomycine

[Traduction par l'éditeur] 


\section{INTRODUCTION}

T he expiry date of IV medications after reconstitution or dilution is often limited to about $24 \mathrm{~h}$ because of the potential for breaks in sterility. However, when reconstitution and dilution are carried out in a sterile environment, according to recommendations in USP Chapter $<797>,{ }^{1}$ the expiry dates for many stable compounds can be extended from $24 \mathrm{~h}$ to 10 or even 14 days. ${ }^{1,2}$ Extending the expiration date could reduce wastage of many drugs ${ }^{3,4}$ and might increase the convenience for an ambulatory patient by eliminating the need for frequent trips to a clinic or visits by a home care nurse to obtain additional doses.

An increasing number of patients are being treated as outpatients. Many of these patients receive their medications by infusion using portable pumps or infusion devices. ${ }^{5}$ The Accufuser infusion device, a silicone-based elastomeric device that is already well established in Europe and Asia, is now being marketed in Canada. Reliable and widely available stability information for the Accufuser device is crucial for the Canadian market. Therefore, studies were undertaken to determine the stability of commonly used antibiotics when stored in the Accufuser device according to recommended storage conditions.

More specifically, the stability of the highest and lowest commonly used concentrations of cefazolin, ceftazidime, ceftriaxone, clindamycin, and vancomycin in 5\% dextrose in water $(\mathrm{D} 5 \mathrm{~W})$ or $0.9 \%$ sodium chloride in water (NS) was evaluated after storage at $4^{\circ} \mathrm{C}$ and at room temperature $\left(23^{\circ} \mathrm{C}\right)$. The concentration of each drug was determined by a validated, stability-indicating liquid chromatographic method.

\section{METHODS}

\section{Liquid Chromatographic Method}

The liquid chromatographic system consisted of an isocratic solvent delivery pump (model P4000; Thermo Separation Products, San Jose, California), which pumped a mixture of acetonitrile (OmniSolv; EMD Chemicals Inc, Gibbstown, New Jersey) and a buffer or other modifiers, as specified in Table 1, through the reverse-phase column, also as specified in Table 1 . The samples were introduced into the liquid chromatographic system using an autoinjector (WISP 712; Waters Scientific, Toronto, Ontario).

The column effluent was monitored with a variablewavelength ultraviolet (UV) detector (UV6000; Thermo Separation Products) at the appropriate wavelength for each drug (as specified in Table 1). The signal from the detector was integrated and recorded with a chromatography data system (ChromQuest, version 5.0; Thermo Fisher Scientific Inc). The area under the peak of interest was subjected to least-squares linear regression, and the actual concentration in each sample was determined by interpolation from the standard curve.
The method for ceftriaxone was similar to a previously published reverse-phase stability-indicating method for this drug, ${ }^{6}$ but the column, mobile phase, and UV wavelength for detection were different. The method for ceftazidime was similar to a previously published reverse-phase stability-indicating method for this drug, ${ }^{7}$ but the column, mobile phase, and UV wavelength for detection were different. The method for vancomycin was similar to a previously published reverse-phase stability-indicating method, ${ }^{8}$ but the flow rate was different.

\section{Assay Validation}

Following set-up of the chromatographic system for each drug, the suitability of the method for use as a stabilityindicating assay was tested by analyzing samples in which degradation of the compound was accelerated by incubation in a water bath at $80^{\circ} \mathrm{C} .^{9-11}$ Samples for assay were withdrawn from each vial immediately before placement in the water bath and on at least 8 other occasions over the study period. Samples were injected directly into the chromatographic system using an autoinjector (WISP 712). The resulting chromatograms were inspected for the appearance of additional peaks, and the peak of interest was compared between samples for changes in concentration, retention time, peak shape, and UV spectral purity (200-320 nm) relative to a fresh, undegraded sample.

Following this first phase of evaluation and validation, the accuracy and reproducibility of the standard curves were tested over 5 days, and system suitability criteria (theoretical plates, tailing, and retention time) were developed to ensure consistent chromatographic performance, according to accepted analytical guidelines. ${ }^{12}$ Standard curves were prepared daily by weighing a quantity of a standard and dissolving it in distilled water. This stock solution was further diluted to prepare 6 standards with final concentrations that encompassed the range of expected concentrations for each drug. Combined with a blank, these standards were used to construct a standard curve. Three or four microlitres of each sample was chromatographed in duplicate. Also, 3 quality control samples were prepared and chromatographed in duplicate each day. The concentration of each quality control sample was determined and compared to the known concentrations, and the percent deviation (accuracy) was calculated. Intraday and interday errors were assessed in terms of the coefficients of variation of the peak areas of both quality control samples and standards.

\section{Stability Study}

On study day 0 for each drug, vials of the particular drug (for which manufacturers, lots, and expiry dates are listed in Table 1) were reconstituted according to the manufacturer's instructions. The nominal concentrations identified in Table 1 were prepared by diluting the required amount of drug into 50-mL polyvinyl chloride (PVC) minibags of D5W (Baxter 


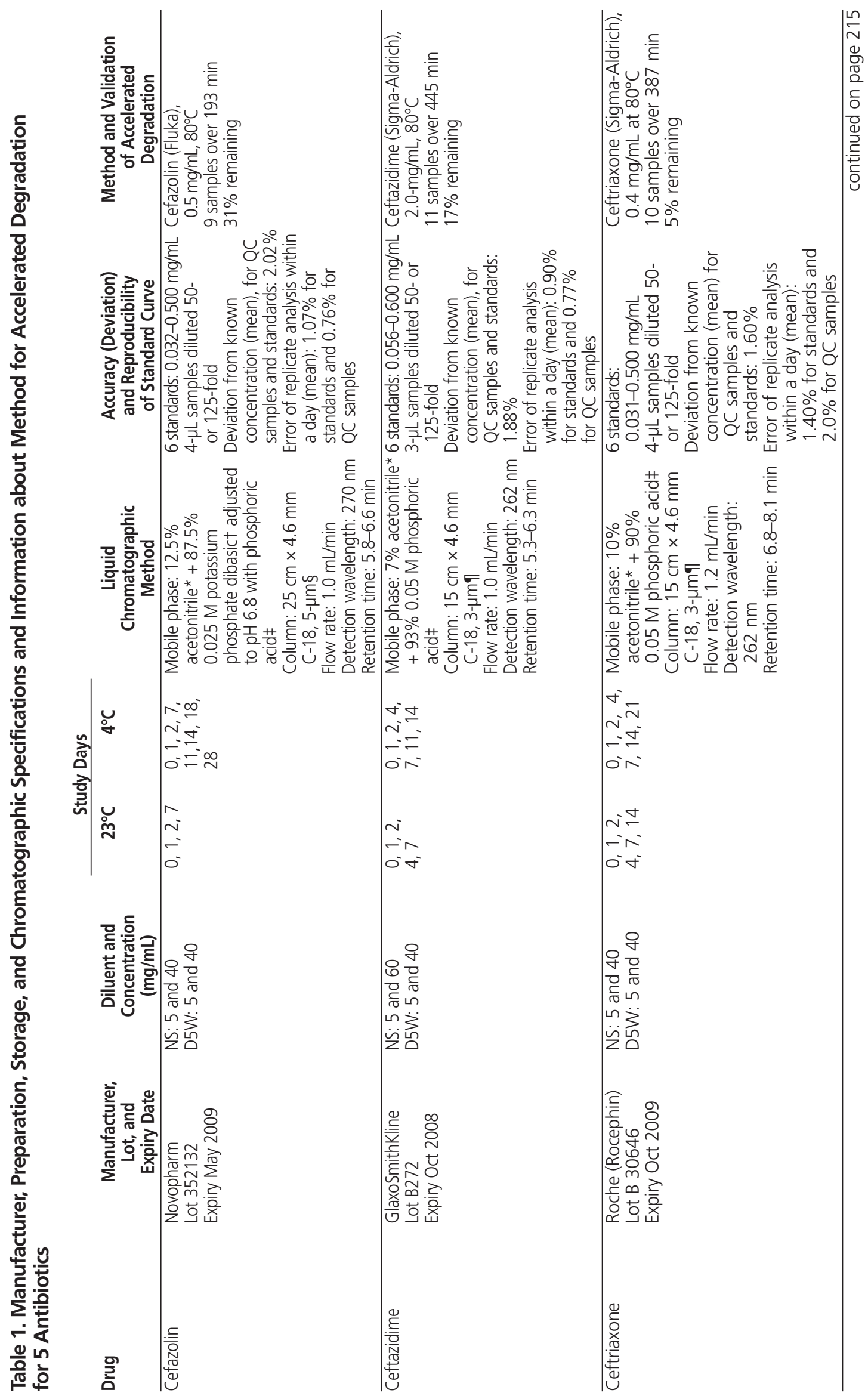




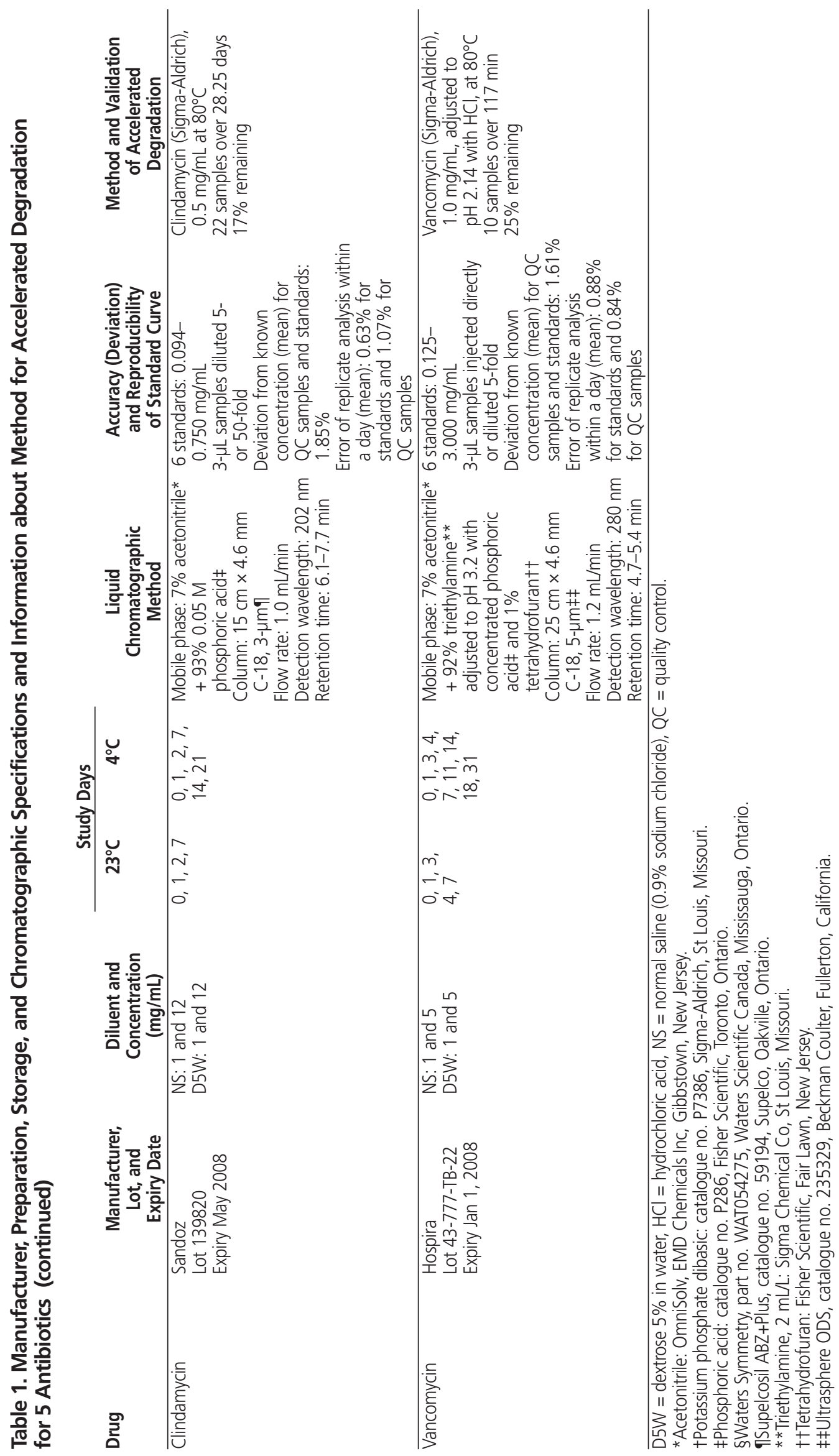


Corporation, Toronto, Ontario; lot P203042, expiry September 2008). In total, 16 D5W minibags were prepared for each drug, 8 for the higher concentration and 8 for the lower concentration (see Table 1). The entire volume of each minibag was then withdrawn from the bag and placed in a $60-\mathrm{mL}$ disposable silicone balloon infuser (Accufuser; Woo Young Medical Co Ltd, model C0005S, rated at $0.5 \mathrm{~mL} / \mathrm{h}$; lot CASAS17, expiry January 4, 2010).

This procedure was repeated to prepare an additional 16 minibags for each drug of interest diluted in NS (Hospira, Montréal, Quebec; lot 49-068-NA, expiry July 1, 2008). Again, the entire volume of each minibag was then withdrawn from the PVC bag and placed in a $60-\mathrm{mL}$ disposable silicone balloon infuser (Accufuser; same lot as noted above).

For each combination of concentration and diluent of a particular drug, 4 Accufuser containers were stored at $4^{\circ} \mathrm{C}$ and
4 were stored at room temperature, unprotected from ambient fluorescent room light. On the study days specified in Table 1, approximately $2-\mathrm{mL}$ samples were drawn from 3 of the 4 Accufuser containers at each temperature for duplicate determination of the concentration of the drug of interest. The fourth container of each set was used for visual inspection of the solution against a white and a black background. Samples for chromatographic analysis were injected directly or were diluted before injection, as specified in Table 1.

\section{Data Reduction and Statistical Analysis}

After determining the coefficient of variation of replicate determinations of concentration, a sample size calculation was completed for each drug. This calculation indicated that 2 replicates were required to ensure that the analytical method could distinguish between concentrations that differed by at

\section{Table 2. Stability of Cefazolin during Storage in Accufuser Elastomeric Infusion Device, Expressed as Percentage of Original Concentration Remaining (Mean \pm SD)*}

\begin{tabular}{|c|c|c|c|c|c|c|c|c|}
\hline \multirow[b]{3}{*}{ Study Day } & \multicolumn{4}{|c|}{ Nominal $5 \mathrm{mg} / \mathrm{mL}$} & \multicolumn{4}{|c|}{ Nominal $40 \mathrm{mg} / \mathrm{mL}$} \\
\hline & \multicolumn{2}{|c|}{ D5W } & \multicolumn{2}{|c|}{ NS } & \multicolumn{2}{|c|}{ D5W } & \multicolumn{2}{|c|}{ NS } \\
\hline & $23^{\circ} \mathrm{C}$ & $4^{\circ} \mathrm{C}$ & $23^{\circ} \mathrm{C}$ & $4^{\circ} \mathrm{C}$ & $23^{\circ} \mathrm{C}$ & $4^{\circ} \mathrm{C}$ & $23^{\circ} \mathrm{C}$ & $4^{\circ} \mathrm{C}$ \\
\hline \multicolumn{9}{|l|}{ Observed initial } \\
\hline $\begin{array}{l}\text { concentration } \\
\text { (mg/L) }\end{array}$ & $4.76 \pm 0.14$ & $4.57 \pm 0.07$ & $4.85 \pm 0.32$ & $4.64 \pm 0.13$ & $32.55 \pm 1.32$ & $33.06 \pm 1.64$ & $31.74 \pm 0.95$ & $33.49 \pm 3.54$ \\
\hline 1 & $98.8 \pm 0.4$ & $102.0 \pm 0.8$ & $96.3 \pm 2.6$ & $102.2 \pm 1.3$ & $97.2 \pm 0.9$ & $100.3 \pm 1.2$ & $102.0 \pm 2.4$ & $100.9 \pm 1.5$ \\
\hline 2 & $95.1 \pm 2.1$ & $102.0 \pm 1.0$ & $95.7 \pm 2.3$ & $101.4 \pm 2.5$ & $93.7 \pm 0.8$ & $95.5 \pm 0.8$ & $97.1 \pm 1.7$ & $98.4 \pm 0.4$ \\
\hline 7 & $91.0 \pm 1.0$ & $99.7 \pm 1.3$ & $91.3 \pm 3.0$ & $100.5 \pm 2.4$ & $93.1 \pm 0.9$ & $97.3 \pm 2.0$ & $94.2 \pm 2.7$ & $99.0 \pm 2.0$ \\
\hline 11 & & $98.9 \pm 0.7$ & & $99.0 \pm 2.4$ & & $97.7 \pm 1.9$ & & $96.5 \pm 0.6$ \\
\hline 14 & & $99.7 \pm 1.1$ & & $98.8 \pm 1.0$ & & $97.7 \pm 2.8$ & & $97.9 \pm 0.8$ \\
\hline 18 & & $99.6 \pm 0.6$ & & $99.8 \pm 1.9$ & & $99.1 \pm 1.2$ & & $99.1 \pm 1.2$ \\
\hline 28 & & $95.1 \pm 0.5$ & & $96.2 \pm 1.8$ & & $95.1 \pm 1.4$ & & $94.0 \pm 1.0$ \\
\hline \multicolumn{9}{|l|}{ Degradation } \\
\hline rate† (\%/day) & -1.256 & -0.194 & -1.082 & -0.164 & -0.808 & -0.097 & -0.957 & -0.179 \\
\hline T-90\% (days)‡ & 7.45 & 59.79 & 7.90 & 69.60 & 9.93 & 90.67 & 11.20 & 56.03 \\
\hline \multicolumn{9}{|l|}{$\begin{array}{l}\text { Fastest } \\
\text { degradation rate§ }\end{array}$} \\
\hline $\begin{array}{l}\text { Lower limit of } \\
95 \% \mathrm{Cl} \text { (\%/day) }\end{array}$ & -2.409 & -0.306 & -2.204 & -0.257 & -2.745 & -0.268 & -2.626 & -0.314 \\
\hline T-90\% (days) & 4.15 & 32.64 & 4.54 & 38.97 & 3.64 & 37.36 & 3.81 & 31.89 \\
\hline
\end{tabular}

\section{Estimated \%}

remaining with

storage $\mathfrak{\eta}$

13.5 days at

$4^{\circ} \mathrm{C}+12 \mathrm{~h}$

at $23^{\circ} \mathrm{C}$

27.5 days at $4^{\circ} \mathrm{C}$

$+8 \mathrm{~h}$ at $23^{\circ} \mathrm{C}$

\subsection{6}

90.37

$\mathrm{CI}=$ confidence interval, D5W $=$ dextrose $5 \%$ in water, NS = normal salin

(

*Each value was based on duplicate determination of 3 samples. The percent remaining was based on the observed concentration on day $0(100 \%)$.

†The degradation rate was determined by linear regression of the percent remaining on each study day.

$\neq \mathrm{T}-90 \%$ is the time for the concentration to decline by $10 \%$ (i.e., time to reach $90 \%$ of initial concentration), as determined from the degradation rate.

§Fastest degradation rate and T-90\% were based on the lower 95\% confidence limit of the regression-determined slope.

IUsing the fastest observed degradation rates determined by regression $(95 \% \mathrm{Cl})$, calculations were completed for a solution stored in an Accufuser elastomeric infusion device for 13.5 or 27.5 days, followed by storage for an additional period at room temperature $\left(23^{\circ} \mathrm{C}\right)$. 
least $10 \% .^{13,14}$ Means were calculated for replicate analyses and are reported in the summary tables. Mean results from different days for each combination of concentration, diluent, and storage temperature were compared statistically to determine if there was an association between the observed result and time (linear regression). Analysis of variance was used to test differences in degradation rate between study days and for different combinations of temperature, diluent, and drug concentration. The 5\% level was used as the a priori cutoff for significance. A beyond-use date was determined as the time taken for the concentration, estimated using the upper limit of the $95 \%$ confidence interval (CI) of the degradation rate, to decline to $90 \%$ of the initial (day 0 ) concentration.

\section{RESULTS}

\section{Accelerated Degradation and Assay Validation}

Degradation of each drug (cefazolin, ceftazidime, ceftriaxone, clindamycin, and vancomycin) with application of heat occurred relatively quickly, such that $31 \%$ or less of the drug of interest remained at the end of the degradation study period (Table 1). Degradation produced additional peaks in each chromatogram, which could be separated from the drug of interest in each case. Given the chromatographic separation of these degradation products from the drug of interest and given the similarity of the UV spectrum (200-320 nm) for fresh and degraded samples of each drug of interest, it was concluded that this analytical method was suitable for indicating stability. ${ }^{9-11}$

For each drug, assay validation demonstrated that the deviation from the known concentration for quality control samples and standards on any day averaged $2.02 \%$ or less. Replicate error within a day averaged less than $2.0 \%$ for quality control and standards (Table 1).

Analysis of accuracy and reproducibility during the study period indicated that the observations made during assay validation were maintained during the study period and that each drug could be measured accurately and reproducibly. System suitability criteria were developed on the basis of daily

Table 3. Stability of Ceftazidime during Storage in Accufuser Elastomeric Infusion Device, Expressed as Percentage of Original Concentration Remaining (Mean \pm SD)*

\begin{tabular}{|c|c|c|c|c|c|c|c|c|}
\hline \multirow[b]{3}{*}{ Study Day } & \multicolumn{4}{|c|}{ Nominal $5 \mathrm{mg} / \mathrm{mL}$} & \multirow{2}{*}{\multicolumn{2}{|c|}{$\frac{\text { Nominal } 40 \mathrm{mg} / \mathrm{mL}}{\mathrm{D} 5 \mathrm{~W}}$}} & \multirow{2}{*}{\multicolumn{2}{|c|}{$\begin{array}{c}\text { Nominal } 60 \mathrm{mg} / \mathrm{mL} \\
\mathrm{NS}\end{array}$}} \\
\hline & \multicolumn{2}{|c|}{ D5W } & \multicolumn{2}{|c|}{ NS } & & & & \\
\hline & $23^{\circ} \mathrm{C}$ & $4^{\circ} \mathrm{C}$ & $23^{\circ} \mathrm{C}$ & $4^{\circ} \mathrm{C}$ & $23^{\circ} \mathrm{C}$ & $4^{\circ} \mathrm{C}$ & $23^{\circ} \mathrm{C}$ & $4^{\circ} \mathrm{C}$ \\
\hline \multicolumn{9}{|l|}{ Observed initial } \\
\hline $\begin{array}{l}\text { concentration } \\
\text { (mg/L) }\end{array}$ & $5.60 \pm 0.22$ & $5.50 \pm 0.38$ & $5.88 \pm 0.20$ & $5.82 \pm 0.16$ & $40.45 \pm 1.26$ & $39.86 \pm 0.56$ & $60.00 \pm 2.87$ & $58.13 \pm 2.45$ \\
\hline 1 & $97.0 \pm 3.0$ & $101.3 \pm 1.8$ & $101.0 \pm 1.0$ & $101.3 \pm 0.3$ & $92.3 \pm 2.1$ & $99.7 \pm 1.2$ & $93.2 \pm 0.9$ & $98.7 \pm 1.1$ \\
\hline 2 & $92.7 \pm 2.3$ & $100.6 \pm 0.4$ & $98.0 \pm 1.0$ & $101.5 \pm 1.0$ & $81.9 \pm 0.3$ & $94.4 \pm 1.0$ & $85.9 \pm 2.0$ & $96.9 \pm 1.4$ \\
\hline 4 & $74.3 \pm 1.5$ & $96.1 \pm 2.5$ & $85.9 \pm 3.7$ & $98.0 \pm 1.6$ & $64.9 \pm 0.8$ & $88.1 \pm 0.9$ & $73.7 \pm 1.7$ & $92.9 \pm 2.4$ \\
\hline 7 & $61.7 \pm 1.0$ & $90.1 \pm 1.4$ & $79.8 \pm 5.3$ & $99.1 \pm 0.3$ & $52.2 \pm 1.2$ & $84.5 \pm 3.2$ & $60.6 \pm 5.4$ & $91.4 \pm 2.4$ \\
\hline 11 & & $87.1 \pm 1.5$ & & $97.4 \pm 3.9$ & & $78.5 \pm 1.7$ & & $89.1 \pm 4.9$ \\
\hline 14 & & $84.0 \pm 1.5$ & & $94.3 \pm 2.4$ & & $77.1 \pm 2.1$ & & $87.9 \pm 2.7$ \\
\hline \multicolumn{9}{|l|}{ Degradation rate } \\
\hline (\%/day) & -5.86 & -1.30 & -3.03 & -0.42 & -6.96 & -1.72 & -5.63 & -0.86 \\
\hline T-90\% (days)‡ & 1.97 & 8.78 & 3.69 & 26.36 & 1.11 & 4.94 & 1.50 & 10.06 \\
\hline \multicolumn{9}{|l|}{$\begin{array}{l}\text { Fastest } \\
\text { degradation rate§ }\end{array}$} \\
\hline $\begin{array}{l}\text { Lower limit of } \\
95 \% \mathrm{Cl} \text { (\%/day) }\end{array}$ & -7.61 & -1.62 & -4.95 & -0.67 & -9.22 & -2.25 & -6.76 & -1.15 \\
\hline T-90\% (days) & 1.31 & 6.19 & 2.02 & 15.01 & 1.09 & 4.45 & 1.48 & 8.68 \\
\hline \multicolumn{9}{|l|}{$\begin{array}{l}\text { Estimated \% } \\
\text { remaining with } \\
\text { storage }\end{array}$} \\
\hline $\begin{array}{l}6.5 \text { days at } 4^{\circ} \mathrm{C} \\
+12 \mathrm{~h} \text { at } 23^{\circ} \mathrm{C}\end{array}$ & & 86.70 & & 93.91 & & 81.95 & & 90.07 \\
\hline $\begin{array}{l}2.5 \text { days at } 4^{\circ} \mathrm{C} \\
+8 \text { h at } 23^{\circ} \mathrm{C}\end{array}$ & & 93.16 & & 96.57 & & 90.94 & & 94.67 \\
\hline
\end{tabular}

$\mathrm{Cl}=$ confidence interval, D5W = dextrose $5 \%$ in water, NS = normal saline (0.9\% sodium chloride), SD = standard deviation.

*Each value was based on duplicate determination of 3 samples. The percent remaining was based on the observed concentration on day $0(100 \%)$.

†The degradation rate was determined by linear regression of the percent remaining on each study day.

₹T-90\% is the time for the concentration to decline by $10 \%$ (i.e., time to reach $90 \%$ of initial concentration), as determined from the degradation rate.

§Fastest degradation rate and T-90\% were based on the lower 95\% confidence limit of the regression-determined slope. IUsing the fastest observed degradation rates determined by regression $(95 \% \mathrm{Cl})$, calculations were completed for a solution stored in an Accufuser elastomeric infusion device for 6.5 or 2.5 days, followed by storage for an additional period at room temperature $\left(23^{\circ} \mathrm{C}\right)$. 
calculations of theoretical plates, tailing, retention time, and accuracy observed during the validation period and were used to ensure continued chromatographic performance during the study period. On each day, the strength of the mobile phase was prepared to ensure a specific retention time for each drug. The mobile phases used in the study produced retention times in the range of 5-8 minutes for each compound of interest (Table 1).

\section{Stability of Cefazolin}

The initial concentration and the percent remaining on each study day for each cefazolin solution are reported in Table 2. Analysis of variance revealed differences in percent remaining due to temperature $(p<0.001)$ and study day $(p=0.016)$, but not concentration $(p=0.25)$ or diluent $(p=0.43)$. The lack of effect of concentration and diluent on degradation is indicated by the limited variation in the amount remaining on day 28 , in either NS or D5W, at either concentration, after storage at $4^{\circ} \mathrm{C}$ (94.0\% to $96.2 \%)$.

At room temperature, between $6 \%$ and $9 \%$ of the initial concentration was lost within 7 days, which corresponds to a degradation rate of between $0.8 \%$ and $1.2 \%$ per day. When stored in the refrigerator $\left(4^{\circ} \mathrm{C}\right)$, degradation occurred more slowly, such that between $3 \%$ and $6 \%$ of the initial concentration was lost within 28 days. This corresponds to a degradation rate of between $0.1 \%$ and $0.2 \%$ per day.

For cefazolin prepared in D5W or NS, linear regression based on the fastest degradation rate with $95 \%$ confidence showed that solutions stored at room temperature retained $90 \%$ of the initial concentration for at least 3.64 days (range of lower limit of 95\% CI 3.64-4.54 days). Linear regression based on the fastest degradation rate indicated that samples stored at $4^{\circ} \mathrm{C}$ retained $90 \%$ of the initial concentration for at least 31.89 days (range of lower limit of 95\% CI 31.89-38.97 days).

\section{Stability of Ceftazidime}

The initial concentration and the percent remaining on each study day for each ceftazidime solution are reported in Table 3. Analysis of variance revealed differences in percent remaining due to temperature $(p<0.001)$, study day $(p=0.001)$, concentration $(p=0.006)$, and diluent $(p=0.053)$.

Table 4. Stability of Ceftriaxone during Storage in Accufuser Elastomeric Infusion Device, Expressed as Percentage of Original Concentration Remaining (Mean \pm SD)*

\begin{tabular}{|c|c|c|c|c|c|c|c|c|}
\hline \multirow[b]{3}{*}{ Study Day } & \multicolumn{4}{|c|}{ Nominal $5 \mathrm{mg} / \mathrm{mL}$} & \multicolumn{4}{|c|}{ Nominal $40 \mathrm{mg} / \mathrm{mL}$} \\
\hline & \multicolumn{2}{|c|}{ D5W } & \multicolumn{2}{|c|}{ NS } & \multicolumn{2}{|c|}{ D5W } & \multicolumn{2}{|c|}{ NS } \\
\hline & $23^{\circ} \mathrm{C}$ & $4^{\circ} \mathrm{C}$ & $23^{\circ} \mathrm{C}$ & $4^{\circ} \mathrm{C}$ & $23^{\circ} \mathrm{C}$ & $4^{\circ} \mathrm{C}$ & $23^{\circ} \mathrm{C}$ & $4^{\circ} \mathrm{C}$ \\
\hline \multicolumn{9}{|l|}{ Observed initial } \\
\hline $\begin{array}{l}\text { concentration } \\
\text { (mg/L) }\end{array}$ & $5.65 \pm 0.47$ & $5.14 \pm 0.29$ & $5.10 \pm 0.42$ & $5.77 \pm 0.85$ & $42.14 \pm 3.83$ & $42.69 \pm 0.22$ & $42.44 \pm 2.04$ & $45.45 \pm 1.99$ \\
\hline 1 & $97.0 \pm 2.2$ & $101.0 \pm 4.3$ & $98.7 \pm 3.8$ & $104.7 \pm 14.5$ & $97.8 \pm 9.7$ & $97.2 \pm 0.7$ & $96.7 \pm 1.6$ & $97.94 \pm 3.2$ \\
\hline 2 & $94.5 \pm 3.6$ & $97.4 \pm 1.6$ & $93.3 \pm 6.1$ & $104.8 \pm 11.9$ & $95.8 \pm 0.3$ & $99.3 \pm 4.6$ & $94.5 \pm 4.6$ & $98.2 \pm 3.1$ \\
\hline 4 & $92.6 \pm 4.6$ & $96.4 \pm 0.7$ & $92.6 \pm 7.6$ & $105.8 \pm 15.6$ & $95.6 \pm 0.8$ & $97.3 \pm 5.1$ & $95.1 \pm 3.4$ & $98.7 \pm 5.8$ \\
\hline 7 & $89.2 \pm 0.6$ & $97.6 \pm 8.2$ & $91.0 \pm 5.7$ & $104.6 \pm 12.8$ & $87.0 \pm 1.0$ & $96.3 \pm 2.0$ & $88.7 \pm 2.1$ & $95.7 \pm 2.4$ \\
\hline 14 & $86.1 \pm 10.7$ & $97.3 \pm 4.1$ & $84.5 \pm 4.6$ & $103.6 \pm 13.1$ & $69.7 \pm 1.2$ & $95.8 \pm 2.4$ & $77.7 \pm 2.6$ & $95.5 \pm 3.0$ \\
\hline 21 & & $94.3 \pm 3.6$ & & $97.4 \pm 13.4$ & & $91.0 \pm 1.9$ & & $89.8 \pm 3.7$ \\
\hline $\begin{array}{l}\text { Degradation rate } \\
\text { (\%/day) } \\
\text { T-90\% (days)‡ }\end{array}$ & $\begin{array}{l}-1.09 \\
7.4\end{array}$ & $\begin{array}{l}-0.22 \\
41.9\end{array}$ & $\begin{array}{l}-0.99 \\
8.1\end{array}$ & $\begin{array}{l}-0.22 \\
65.7\end{array}$ & $\begin{array}{l}-2.15 \\
5.2\end{array}$ & $\begin{array}{l}-0.35 \\
26.1\end{array}$ & $\begin{array}{c}-1.51 \\
6.1\end{array}$ & $\begin{array}{l}-0.41 \\
23.1\end{array}$ \\
\hline \multicolumn{9}{|c|}{$\begin{array}{l}\text { Fastest degradation } \\
\text { rate§ } \\
\text { Lower limit of }\end{array}$} \\
\hline $\begin{array}{l}95 \% \mathrm{Cl} \text { (\%/day) } \\
\text { T-90\% (days) }\end{array}$ & $\begin{array}{l}-1.37 \\
7.3\end{array}$ & $\begin{array}{l}-0.43 \\
23.5\end{array}$ & $\begin{array}{l}-1.23 \\
8.1\end{array}$ & $\begin{array}{l}-0.60 \\
16.7\end{array}$ & $\begin{array}{c}-2.39 \\
4.2\end{array}$ & $\begin{array}{l}-0.52 \\
19.4\end{array}$ & $\begin{array}{l}-1.69 \\
5.9\end{array}$ & $\begin{array}{l}-0.58 \\
17.4\end{array}$ \\
\hline \multicolumn{9}{|l|}{$\begin{array}{l}\text { Estimated \% } \\
\text { remaining with } \\
\text { storageף }\end{array}$} \\
\hline $\begin{array}{l}13 \text { days at } 4^{\circ} \mathrm{C} \\
\text { For } 1 \text { additional }\end{array}$ & & 94.47 & & 92.23 & & 93.30 & & 92.53 \\
\hline day at $23^{\circ} \mathrm{C}$ & & 93.10 & & 91.00 & & 90.91 & & 90.84 \\
\hline \multicolumn{9}{|c|}{ 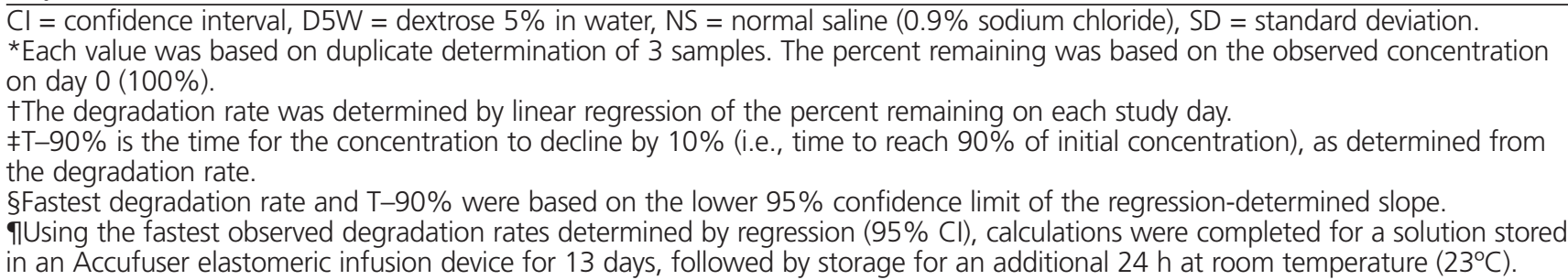 } \\
\hline
\end{tabular}


Table 5. Stability of Clindamycin during Storage in Accufuser Elastomeric Infusion Device, Expressed as Percentage of Original Concentration Remaining (Mean $\pm \mathrm{SD}$ )*

\begin{tabular}{|c|c|c|c|c|c|c|c|c|}
\hline \multirow[b]{3}{*}{ Study Day } & \multicolumn{4}{|c|}{ Nominal $1 \mathrm{mg} / \mathrm{mL}$} & \multicolumn{4}{|c|}{ Nominal $12 \mathrm{mg} / \mathrm{mL}$} \\
\hline & \multicolumn{2}{|c|}{ D5W } & \multicolumn{2}{|c|}{ NS } & \multicolumn{2}{|c|}{ D5W } & \multicolumn{2}{|c|}{ NS } \\
\hline & $23^{\circ} \mathrm{C}$ & $4^{\circ} \mathrm{C}$ & $23^{\circ} \mathrm{C}$ & $4^{\circ} \mathrm{C}$ & $23^{\circ} \mathrm{C}$ & $4^{\circ} \mathrm{C}$ & $23^{\circ} \mathrm{C}$ & $4^{\circ} \mathrm{C}$ \\
\hline $\begin{array}{l}\text { Observed initial } \\
\text { concentration } \\
(\mathrm{mg} / \mathrm{L})\end{array}$ & $0.72+0.05$ & $0.76+0.06$ & $0.77+0.11$ & $0.76+0.09$ & $9.24+0.93$ & $8.77 \pm 0.28$ & $8.92+0.04$ & $9.62+0.49$ \\
\hline 1 & $104.0 \pm 1.9$ & $102.6 \pm 2.8$ & $102.8 \pm 1.7$ & $103.2 \pm 1.9$ & $102.8 \pm 2.9$ & $101.4 \pm 2.8$ & $102.4 \pm 2.6$ & $101.8 \pm 4.8$ \\
\hline 2 & $102.7 \pm 1.4$ & $102.0 \pm 2.1$ & $101.8 \pm 1.2$ & $102.3 \pm 1.3$ & $102.2 \pm 2.8$ & $104.1 \pm 1.5$ & $100.6 \pm 0.9$ & $100.2 \pm 2.8$ \\
\hline 7 & $104.9 \pm 1.4$ & $104.6 \pm 2.1$ & $104.1 \pm 1.7$ & $103.9 \pm 2.0$ & $100.9 \pm 2.9$ & $100.2 \pm 3.3$ & $99.4 \pm 0.6$ & $99.2 \pm 4.8$ \\
\hline 14 & & $104.3 \pm 3.1$ & & $104.5 \pm 0.7$ & & $101.2 \pm 2.4$ & & $100.7 \pm 3.4$ \\
\hline 21 & & $103.0 \pm 1.6$ & & $103.7 \pm 1.5$ & & $99.0 \pm 1.1$ & & $99.1 \pm 5.3$ \\
\hline $\begin{array}{l}\text { Degradation } \\
\text { rate† (\%/day) } \\
\text { T-90\% (days)‡ }\end{array}$ & $\begin{array}{l}0.501 \\
23.2\end{array}$ & $\begin{array}{c}0.108 \\
110.3\end{array}$ & $\begin{array}{c}0.465 \\
23.7\end{array}$ & $\begin{array}{l}0.127 \\
94.2\end{array}$ & $\begin{array}{l}-0.043 \\
269.6\end{array}$ & $\begin{array}{l}-0.107 \\
110.2\end{array}$ & $\begin{array}{l}-0.230 \\
48.4\end{array}$ & $\begin{array}{l}-0.055 \\
193.3\end{array}$ \\
\hline $\begin{array}{l}\text { Fastest } \\
\text { degradation rate§ } \\
\text { Lower limit of } \\
95 \% \mathrm{Cl} \text { (\%/day) } \\
\text { T-90\% (days) }\end{array}$ & $\begin{array}{l}0.891 \\
11.2\end{array}$ & $\begin{array}{l}0.121 \\
82.9\end{array}$ & $\begin{array}{c}0.469 \\
21.3\end{array}$ & $\begin{array}{l}0.076 \\
132.3\end{array}$ & $\begin{array}{l}1.274 \\
7.8\end{array}$ & $\begin{array}{l}0.360 \\
27.8\end{array}$ & $\begin{array}{l}0.230 \\
43.4\end{array}$ & $\begin{array}{l}0.198 \\
50.4\end{array}$ \\
\hline $\begin{array}{l}\text { Estimated } \% \\
\text { remaining with } \\
\text { storage } \\
13 \text { days at } 4^{\circ} \mathrm{C} \\
+24 \mathrm{~h} \text { at } 23^{\circ} \mathrm{C} \\
21 \text { days at } 4^{\circ} \mathrm{C} \\
+24 \mathrm{~h} \text { at } 23^{\circ} \mathrm{C}\end{array}$ & & $\begin{array}{l}97.5 \\
96.6\end{array}$ & & $\begin{array}{l}98.5 \\
97.9\end{array}$ & & 94.0 & & $\begin{array}{l}97.2 \\
95.6\end{array}$ \\
\hline
\end{tabular}

$\mathrm{Cl}=$ confidence interval, D5W = dextrose $5 \%$ in water, NS = normal saline (0.9\% sodium chloride), SD = standard deviation.

*Each value was based on duplicate determination of 3 samples. The percent remaining was based on the observed concentration on day $0(100 \%)$.

†The degradation rate was determined by linear regression of the percent remaining on each study day.

$\neq \mathrm{T}-90 \%$ is the time for the concentration to decline by $10 \%$ (i.e., time to reach $90 \%$ of initial concentration), as determined

from the degradation rate.

§Fastest degradation rate and T-90\% were based on the lower 95\% confidence limit of the regression-determined slope.

ףUsing the fastest observed degradation rates determined by regression $(95 \% \mathrm{Cl})$, calculations were completed for a solution stored in an Accufuser elastomeric infusion device for 13 or 21 days, followed by storage for an additional period at room temperature $\left(23^{\circ} \mathrm{C}\right)$.

Although not statistically significant, the result for diluent indicates that ceftazidime degraded slower in NS than in D5W. Given the differences due to concentration, diluent, and temperature, the results for each diluent were evaluated separately, as described below.

In NS: Linear regression showed that solutions of ceftazidime $5 \mathrm{mg} / \mathrm{mL}$ in NS stored at room temperature retained $90 \%$ of the initial concentration for 3.69 days (lower limit of $95 \%$ CI 2.02 days). At $4^{\circ} \mathrm{C}, 90 \%$ of the initial concentration was retained for 26.36 days (lower limit of $95 \%$ CI 15.01 days). Increasing the concentration to $60 \mathrm{mg} / \mathrm{mL}$ shortened the time to reach $90 \%$ of the initial concentration to 1.50 days (lower limit of $95 \%$ CI 1.48 days) with storage at room temperature. With storage at $4^{\circ} \mathrm{C}, 90 \%$ of the initial concentration was retained for 10.06 days (lower limit of $95 \%$ CI 8.68 days).

In D5W: Linear regression showed that solutions of ceftazidime $5 \mathrm{mg} / \mathrm{mL}$ in $\mathrm{D} 5 \mathrm{~W}$ stored at room temperature retained $90 \%$ of the initial concentration for 1.97 days (lower limit of $95 \%$ CI 1.31 days). When stored at $4^{\circ} \mathrm{C}, 90 \%$ of the initial concentration was retained for 8.78 days (lower limit of $95 \%$ CI 6.19 days). Increasing the concentration to $40 \mathrm{mg} / \mathrm{mL}$ shortened the time to reach $90 \%$ of the initial concentration to 1.11 days (lower limit of 95\% CI 1.09 days) with storage at room temperature. With storage at $4^{\circ} \mathrm{C}, 90 \%$ of the initial concentration was retained for 4.94 days (lower limit of $95 \%$ CI 4.45 days).

\section{Stability of Ceftriaxone}

The initial concentration and the percent remaining on each study day for each ceftriaxone solution are reported in Table 4. Analysis of variance revealed differences in percent remaining due to temperature $(p<0.001)$, study day $(p<0.001)$, and concentration $(p=0.019)$, but not diluent $(p=0.16)$.

During storage of this drug at $4^{\circ} \mathrm{C}$, all samples retained more than $95 \%$ of the initial concentration for 14 days. On the basis of the fastest degradation rate observed, with $95 \%$ confidence, more than $91.6 \%$ the initial concentration remained in all Accufuser containers stored at $4^{\circ} \mathrm{C}$ on study day 14 . 
Table 6. Stability of Vancomycin during Storage in Accufuser Elastomeric Infusion Device, Expressed as Percentage of Original Concentration Remaining (Mean \pm SD)*

\begin{tabular}{|c|c|c|c|c|c|c|c|c|}
\hline \multirow[b]{3}{*}{ Study Day } & \multicolumn{4}{|c|}{ Nominal $1 \mathrm{mg} / \mathrm{mL}$} & \multicolumn{4}{|c|}{ Nominal $5 \mathrm{mg} / \mathrm{mL}$} \\
\hline & \multicolumn{2}{|c|}{ D5W } & \multicolumn{2}{|c|}{ NS } & \multicolumn{2}{|c|}{ D5W } & \multicolumn{2}{|c|}{ NS } \\
\hline & $23^{\circ} \mathrm{C}$ & $4^{\circ} \mathrm{C}$ & $23^{\circ} \mathrm{C}$ & $4^{\circ} \mathrm{C}$ & $23^{\circ} \mathrm{C}$ & $4^{\circ} \mathrm{C}$ & $23^{\circ} \mathrm{C}$ & $4^{\circ} \mathrm{C}$ \\
\hline \multicolumn{9}{|l|}{ Observed initial } \\
\hline $\begin{array}{l}\text { concentration } \\
\text { (mg/L) }\end{array}$ & $1.00 \pm 0.09$ & $1.10 \pm 0.10$ & $1.03 \pm 0.03$ & $1.02 \pm 0.09$ & $4.19 \pm 0.35$ & $4.14 \pm 0.52$ & $4.29 \pm 0.25$ & $4.01 \pm 0.14$ \\
\hline 1 & $99.1 \pm 1.0$ & $98.8 \pm 1.2$ & $99.8 \pm 1.6$ & $100.5 \pm 1.3$ & $97.6 \pm 0.8$ & $100.0 \pm 1.5$ & $98.2 \pm 1.6$ & $99.8 \pm 1.8$ \\
\hline 3 & $96.9 \pm 1.0$ & $96.7 \pm 2.3$ & $97.9 \pm 0.6$ & $99.5 \pm 1.2$ & $96.6 \pm 1.2$ & $101.8 \pm 2.3$ & $95.2 \pm 1.4$ & $98.1 \pm 4.2$ \\
\hline 4 & $99.0 \pm 0.9$ & $100.3 \pm 2.1$ & $98.8 \pm 0.6$ & $99.5 \pm 2.2$ & $98.1 \pm 1.9$ & $98.3 \pm 1.6$ & $97.8 \pm 5.0$ & $101.9 \pm 2.9$ \\
\hline 7 & $99.0 \pm 0.9$ & $101.3 \pm 2.1$ & $98.0 \pm 0.5$ & $101.6 \pm 1.5$ & $95.3 \pm 2.9$ & $100.3 \pm 1.7$ & $96.9 \pm 1.5$ & $99.7 \pm 1.6$ \\
\hline 11 & & $98.5 \pm 2.5$ & & $98.2 \pm 1.6$ & & $99.1 \pm 0.8$ & & $98.2 \pm 0.8$ \\
\hline 14 & & $98.4 \pm 2.1$ & & $97.7 \pm 1.3$ & & $97.0 \pm 0.4$ & & $98.2 \pm 0.3$ \\
\hline 18 & & $98.3 \pm 1.1$ & & $98.4 \pm 3.0$ & & $97.9 \pm 1.7$ & & $96.9 \pm 0.5$ \\
\hline 31 & & $97.1 \pm 1.2$ & & $98.3 \pm 1.5$ & & $97.9 \pm 0.3$ & & $98.0 \pm 0.9$ \\
\hline \multicolumn{9}{|l|}{ Degradation } \\
\hline $\begin{array}{l}\text { ratet (\%/day) } \\
\text { T_- }\end{array}$ & $\begin{array}{l}-0.102 \\
8913\end{array}$ & $\begin{array}{l}-0.068 \\
13952\end{array}$ & $\begin{array}{l}-0.287 \\
33.91\end{array}$ & $\begin{array}{l}-0.079 \\
12775\end{array}$ & $\begin{array}{l}-0.531 \\
1720\end{array}$ & $\begin{array}{l}-0.100 \\
10138\end{array}$ & $\begin{array}{l}-0.359 \\
2427\end{array}$ & $\begin{array}{l}-0.091 \\
10874\end{array}$ \\
\hline \multirow{2}{*}{\multicolumn{7}{|c|}{$\begin{array}{l}\text { Fastest } \\
\text { degradation rate§ }\end{array}$}} & 24.21 & 108.24 \\
\hline & & & & & & & & \\
\hline $95 \%$ Cl (\%/day) & -0.832 & -0.188 & -0.673 & -0.167 & -1.174 & -0.204 & -1.325 & -0.200 \\
\hline T-90\% (days) & 12.02 & 53.35 & 14.87 & 59.79 & 8.52 & 49.06 & 7.55 & 50.01 \\
\hline \multicolumn{9}{|l|}{$\begin{array}{l}\text { Estimated \% } \\
\text { remaining with } \\
\text { storageी } \\
13 \text { davs at } 4^{\circ} \mathrm{C}\end{array}$} \\
\hline $\begin{array}{l}+24 \mathrm{~h} \text { at } 23^{\circ} \mathrm{C} \\
29 \text { days at } 4^{\circ} \mathrm{C}\end{array}$ & & 96.73 & & 97.15 & & 96.18 & & 96.08 \\
\hline$+48 \mathrm{~h}$ at $23^{\circ} \mathrm{C}$ & & 92.90 & & 93.81 & & 91.74 & & 91.55 \\
\hline \multicolumn{9}{|c|}{ 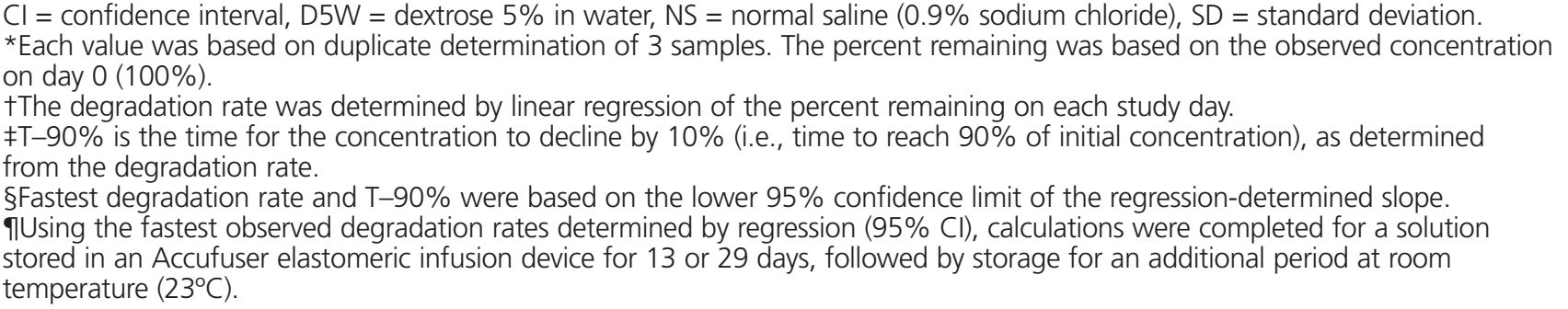 } \\
\hline
\end{tabular}

During storage of this drug at room temperature, all samples retained at least $93.3 \%$ of the initial concentration for 2 days. On the basis of the fastest degradation rate observed, with $95 \%$ confidence, more than $95.2 \%$ of the initial concentration remained in all containers on study day 2 after storage at room temperature.

\section{Stability of Clindamycin}

The initial concentration and the percent remaining on each study day for each clindamycin solution are reported in Table 5. Analysis of variance revealed differences in percent remaining due to study day $(p=0.002)$ and concentration $(p=0.003)$, but not temperature $(p=0.64)$ or diluent $(p=0.38)$. However, even though concentration seemed to be a significant predictor of degradation rate, the degradation of clindamycin was slow, and less than 5\% loss occurred at each concentration, in each diluent, at each temperature. Conversely, although there appeared to be a 2- to 4-fold increase in degradation rate with the increase in temperature from $4{ }^{\circ} \mathrm{C}$ to room temperature, this difference was not significant $(p=0.64)$. Therefore, although Table 5 shows differences in the time to achieve $90 \%$ of the initial concentration, the slow rate of degradation meant that every one of the estimates for T-90\% exceeded the study period. As such, these extimates represent extrapolation and should not be used to establish the expiry date of this drug.

At room temperature, the change relative to initial concentration was less that $5 \%$ over 7 study days. Similarly, when stored in the refrigerator at $4^{\circ} \mathrm{C}$, the concentration changed by less than $3.7 \%$ during the 21 -day study period.

In D5W or NS, linear regression based on the fastest degradation rate, with $95 \%$ confidence, showed that solutions of clindamycin stored at room temperature retained $90 \%$ of the initial concentration for at least 7.8 days (range of lower limit 
Table 7. Time (in Days) Required for $10 \%$ Reduction in Concentration (T-90\%)

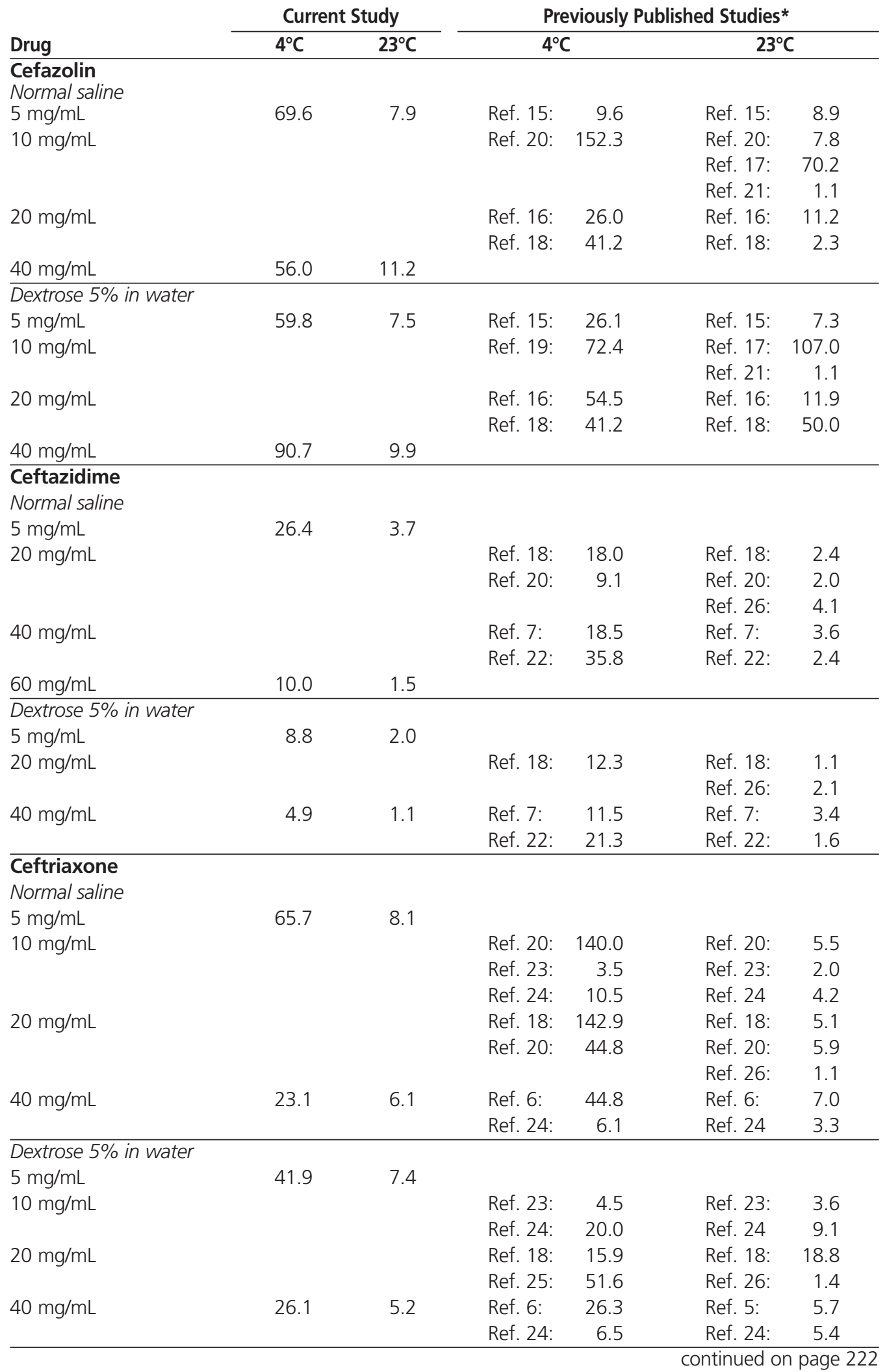




\section{Table 7. Time (in Days) Required for $10 \%$ Reduction in Concentration (T-90\%) (continued)}

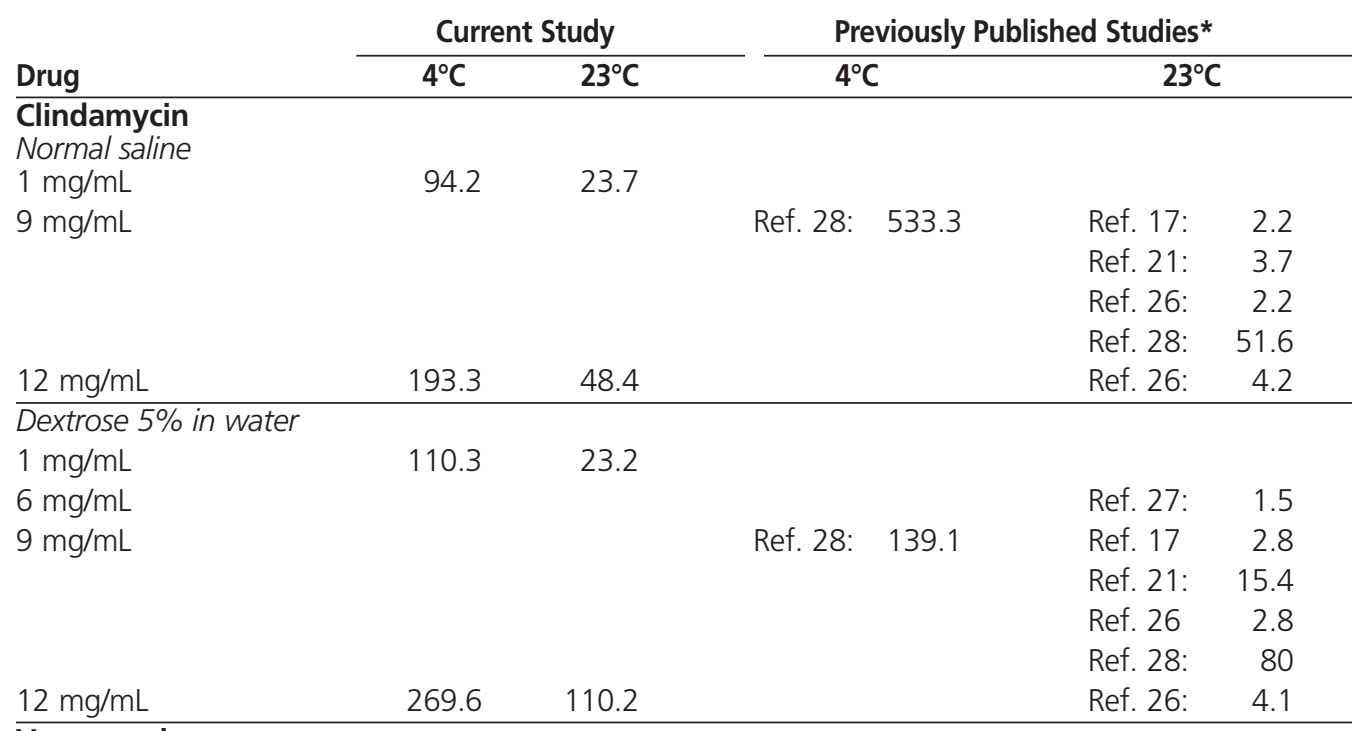

\begin{tabular}{|c|c|c|c|c|c|c|}
\hline $\begin{array}{l}\text { Vancomycin } \\
\text { Norma/ saline }\end{array}$ & & & & & & \\
\hline $1 \mathrm{mg} / \mathrm{mL}$ & 127.8 & 33.9 & & & & \\
\hline 4 mg/mL & & & Ref. 8: & 89.6 & Ref. 8: & 23.6 \\
\hline 5 mg/mL & 108.2 & 24.27 & Ref. 8: & 100.5 & Ref. 8: & 23.6 \\
\hline & & & Ref. 29 & 643.6 & Ref. 29: & 29.0 \\
\hline Dextrose $5 \%$ ir & & & & & & \\
\hline $1 \mathrm{mg} / \mathrm{mL}$ & 139.5 & 89.1 & & & & \\
\hline 4 mg/mL & & & Ref. 8: & 29.9 & Ref. 8: & 16.6 \\
\hline $5 \mathrm{mg} / \mathrm{mL}$ & 101.4 & 17.2 & Ref. 8: & 42.1 & Ref. 8: & 15.9 \\
\hline & & & Ref. 29 & 595.5 & Ref. 29: & 32.4 \\
\hline & & & Ref. 30 & 314.7 & & \\
\hline & & & Ref. 31 & >999.0 & & \\
\hline 10 mg/mL & & & Ref. 30 & 555.2 & & \\
\hline
\end{tabular}

of $95 \%$ CI 7.8-43.4 days), and solutions stored at $4^{\circ} \mathrm{C}$ retained $90 \%$ of the initial concentration for at least 27.8 days (range of lower limit of $95 \%$ CI $27.8-132.3$ days).

\section{Stability of Vancomycin}

The initial concentration and the percent remaining on each study day for each vancomycin solution are reported in Table 6. Analysis of variance revealed differences in percent remaining due to temperature $(p<0.001)$, and study day $(p=0.028)$, but not concentration $(p=0.17)$ or diluent $(p=0.62)$. The lack of an effect of concentration or diluent on degradation is indicated by the observation on day 31 that the amount remaining in the NS and D5W solutions at both initial concentrations after storage at $4^{\circ} \mathrm{C}$ varied between $97.1 \%$ and $98.3 \%$.

At room temperature, between $1 \%$ and $5 \%$ of the initial concentration was lost within 7 days. This corresponds to a degradation rate between $0.10 \%$ and $0.53 \%$ per day (Table 6).
At $4^{\circ} \mathrm{C}$, degradation occurred more slowly, such that between $2 \%$ and $3 \%$ of the initial concentration was lost within 31 days. This corresponds to a degradation rate between $0.07 \%$ and $0.10 \%$ per day (Table 6).

Linear regression based on the fastest degradation rate, with $95 \%$ confidence, showed that solutions of vancomycin in D5W or NS retained $90 \%$ of the initial concentration for at least 7.55 days (range of lower limit of 95\% CI 7.55-14.87 days) when stored at room temperature and at least 49.06 days (range of lower limit of 95\% CI 49.06-59.79 days) when stored at $4^{\circ} \mathrm{C}$.

\section{DISCUSSION}

The stability of cefazolin, ceftazidime, ceftriaxone, and vancomycin were all affected by temperature (with faster degradation at room temperature relative to $4^{\circ} \mathrm{C}$ ) but not diluent, ceftazidime being the only drug with a result that was 


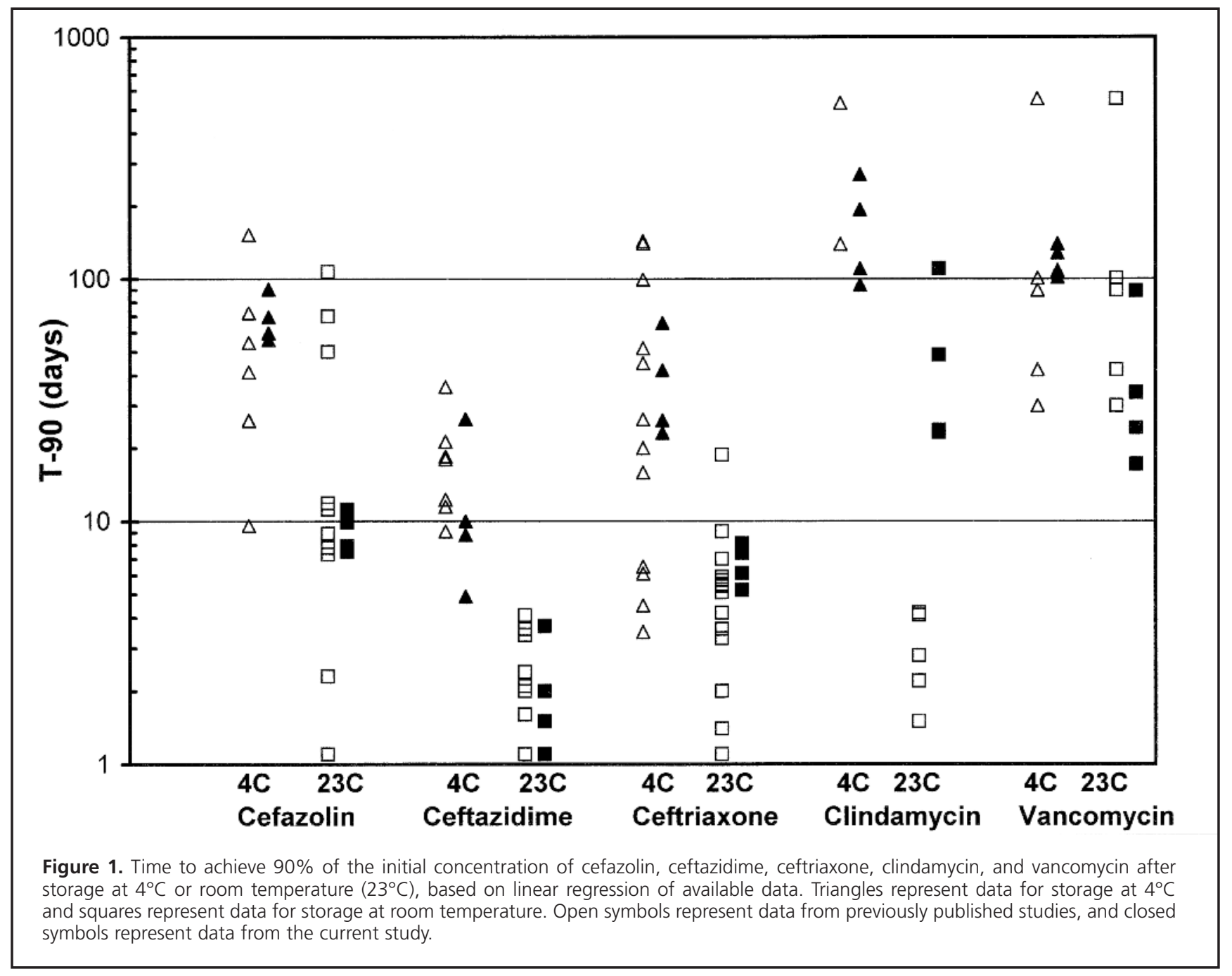

close to statistical significance for diluent $(p=0.053)$. Initial concentration significantly affected the degradation of ceftazidime, ceftriaxone, and clindamycin, but not cefazolin or vancomycin. When the amount remaining, based on the fastest degradation rate with $95 \%$ confidence, was used to determine the amount remaining for a solution stored at $4^{\circ} \mathrm{C}$ and then removed from the refrigerator and stored at room temperature, an expiry date or beyond-use date can be calculated. The recommended expiry dates calculated in this manner are reported in the last row of Tables 2 through 6.

Previously published studies for cefazolin, ${ }^{15-21}$ ceftazidime, $, 1,8,20,22$ ceftriaxone, ${ }^{6,18,20,23-26}$ clindamycin, ${ }^{17,21,26-28}$ and vancomycin ${ }^{8,22-31}$ all reported stability data and expiration dates that were in general agreement with the results reported here. In some cases, the recommended expiry dates in those previously studies were longer than those determined in the current study, largely because the beyond-use dates calculated here were based on 95\% CIs, whereas 95\% CIs were not calculated in most of the earlier studies. ${ }^{6-8,15-24,26-30}$ Previously published studies often used only linear regression to calculate the percent remaining on the last study day. The time to reach $90 \%$ of the initial concentra- tion (T-90\%) can be calculated on the basis of the observed concentration remaining as reported in previous publications ${ }^{6-8,15-31}$ and compared to the T-90\% determined for each drug in the current study (Table 7, Figure 1). Calculation of T-90\% yields a better overall estimate of expiry date because it minimizes the effect of study duration and day-to-day variability in the estimates of concentration. In Table 7, the effect of concentration is evident for ceftriaxone, ceftazidime, and clindamycin. Similarly, in Table 7 and Figure 1, the effect of temperature on concentration is evident for all 5 drugs. The effect of diluent was less obvious, but is evident for ceftazidime in Table 7. These observations are in agreement with analysis of variance results from the current study. Inspection of Table 7 and Figure 1 also reveals tremendous variation between studies in the time to achieve $90 \%$ of the initial concentration. For example, for cefazolin stored at room temperature, the time to reach $90 \%$ varied from 1.1 to 107 days. ${ }^{15-18,20,21}$ The least variation appears to have been reported for ceftazidime, for which the time to reach $90 \%$ of the initial concentration varied from 9.1 to 35.8 days at $4^{\circ} \mathrm{C}$ and from 1.1 to 4.1 days at room temperature ${ }^{7,18,20,22}$ (Table 7, Figure 1). It is apparent from the work reported here 
that the Accufuser infusion device did not adversely affect the stability of these drugs (Table 7, Figure 1).

We conclude that cefazolin, ceftazidime, ceftriaxone, clindamycin, and vancomycin diluted in D5W or NS and stored in an Accufuser infusion device can be assigned the expiry dates reported in Tables 2 to 6 , respectively. The beyonduse dates for cefazolin, clindamycin, and vancomycin suggested here exceed the maximum beyond-use dates in USP Chapter $<797>,{ }^{1}$ which recommended that dates beyond 14 days be used for low-risk compounded products only if sterility testing has been completed on a specified number of units before release. In all cases, the expiry dates provided in this study should be used only after due consideration of sterility and the contamination rate in a particular sterile IV additive program.

\section{References}

1. Kastango ES, Bradshaw BD. USP chapter 797: establishing a practice standard for compounding sterile preparations in pharmacy. Am J Health Syst Pharm 2004;61(18):1928-1938.

2. Trissel LA. The new national standard for sterile preparation. Hosp Pharm 2004 Sep;39:900-904.

3. Walker SE, Hanabusa Y, Dranitsaris G, Bartle WR, Iazzetta J. Cost effective evaluation of a stability study. Can J Hosp Pharm 1987;40(4):113-118.

4. Walker SE, DeAngelis C, Iazzetta J, Gafni A. Chemotherapy waste reduction through shelf-life extension. Can J Hosp Pharm 1994;47(1):15-23.

5. Skryabina EA, Dunn TS. Disposable infusion pumps. Am J Health Syst Pharm 2006;63(13):1260-1268.

6. Walker SE, Dranitsaris G. Stability of reconstituted ceftriaxone in dextrose and saline solutions. Can J Hosp Pharm 1987;40(5):161-166.

7. Walker SE, Dranitsaris G. Stability of reconstituted ceftazidime in dextrose and saline solutions. Can J Hosp Pharm 1988;41(2):65-71.

8. Walker SE, Birkhans B. Stability of intravenous vancomycin. Can J Hosp Pharm 1988;41(5):233-238.

9. Trissel LA. Avoiding common flaws in stability and compatibility studies of injectable drugs. Am J Hosp Pharm 1983;40(7):1159-1160.

10. Trissel LA, Flora KP. Stability studies: five years later. Am J Hosp Pharm 1988;45(7):1569-1571.

11. Policy for publication of chemical stability study manuscripts. Can J Hosp Pharm 1990;43(1):3-4.

12. Shah VP, Midha KK, Dighe S, McGilveray IJ, Skelly JP, Yacobi A, et al. Analytical methods validation: bioavailability, bioequivalence and pharmacokinetic studies. J Pharm Sci 1992;81(3):309-312.

13. Frieman JA, Chalmers TC, Smith H Jr, Kuebler RR. The importance of beta, type II error and sample size in the design and interpretation of the randomized control trial. Survey of 71 "negative" trials. N Engl J Med 1978;299(13):690-694.

14. Stolley PD, Strom BL. Sample size calculations for clinical pharmacology studies. Clin Pharmacol Ther 1986;39(5):489-490.

15. Bornstein M, Thomas PN, Coleman DL, Bylan JC. Stability of parenteral solutions of cefazolin sodium. Am J Hosp Pharm 1974;31(3):296-298.

16. Gupta VD, Stewart KR. Quantitation of carbenicillin disodium, cefazolin sodium, cephalothin sodium, nafcillin sodium, and ticarcillin disodium by high-pressure liquid chromatography. J Pharm Sci 1980;69(11):1264-1267.

17. Bosso JA, Townsend RJ. Stability of clindamycin phosphate and ceftizoxime sodium, cefoxitin sodium, cefamandole nafate, or cefazolin sodium in two intravenous solutions. Am J Hosp Pharm 1985;42(10):2211-2214.

18. Allen LV Jr, Stiles ML, Prince SJ, Smeeding J. Stability of 14 drugs in the latex reservoir of an elastomeric infusion device. Am J Health Syst Pharm 1996;53(22):2740-2743.

19. Galanti LM, Hecq JD, Vanbeckbergen D, Jamart J. Long-term stability of cefuroxime and cefazolin sodium in intravenous infusions. J Clin Pharm Ther 1996;21(3):185-189
20. Xu QA, Trissel LA, Saenz CA, Ingram DS, Williams KY. Stability of three cephalosporin antibiotics in AutoDose Infusion System bags. J Am Pharm Assoc 2002;42(3):428-431.

21. Zbrozek AS, Marble DA, Bosso JA. Compatibility and stability of cefazolin sodium, clindamycin phosphate and gentamicin sulfate in two intravenous solutions. Drug Intell Clin Pharm 1988;22(11):873-875.

22. Das Gupta V, Bethea C, dela Torre M. Chemical stabilities of cefoperazone sodium and ceftazidime in 5\% dextrose and $0,9 \%$ sodium chloride injections. J Clin Pharm Ther 1988;13(3):199-205.

23. Nahata MC. Stability of ceftriaxone sodium in intravenous solutions. $A m$ J Hosp Pharm 1983;40(12):2193-2194.

24. Bailey LC, Tang KT, Medwick T. Stability of ceftriaxone sodium in infusionpump syringes. Am J Hosp Pharm 1993;50(10):2092-2094.

25. Hecq JD, Evrard JM, Vanbeckbergen DF, Jamart J, Galanti LM. Effect of freezing, long term storage and microwave thawing on the stability of ceftriaxone sodium in $5 \%$ dextrose infusion polyolefin bags at $2-8^{\circ} \mathrm{C}$. Eur J Hosp Pharm Sci 2006;12(3):52-56.

26. Marble DA, Bosso JA, Townsend RJ. Stability of clindamycin phosphate with aztreonam, ceftazidime sodium, ceftriaxone sodium, or piperacillin sodium in two intravenous solutions. Am J Hosp Pharm 1986;43(7):1732-1736.

27. Holmes CJ, Ausman RK, Kundsin RB, Walter CW. Effect of freezing and micrwave thawing on the stability of six antibiotic admixtures in plastic bags. Am J Hosp Pharm 1982;39(1):104-108.

28. Porter WR, Johnson CA, Chon MS, Gillespie W. Compatibility and stability of clindamycin phosphate with intravenous fluids. Am J Hosp Pharm 1983 Jan;40:91-94.

29. Das Gupta V, Stewart KR, Nohria S. Stability of vancomycin hydrochloride in $5 \%$ dextrose and $0.9 \%$ sodium chloride injections. Am J Hosp Pharm 1986;43(7):1729-1731

30. Galanti LM, Hecq JD, Vanbeckbergen D, Jamart J. Long term stability of vancomycin hydrochloride in intravenous infusions. J Clin Pharm Ther 1997;22(5):353-356.

31. Rodenbach MP, Hecq JD, Vanbeckbergen D, Jamart J, Galanti G. Effect of freezing, long-term storage, and microwave thawing on the stability of vancomycine hydrochloride in 5\% dextrose infusions. Eur J Hosp Pharm Sci 2005;11(5):111-113.

Scott E Walker, MScPhm, FCSHP, is Co-ordinator, Research and Quality Control, Department of Pharmacy and Division of Pharmacology, Sunnybrook Health Sciences Centre and Associate Professor, Faculty of Pharmacy, University of Toronto, Toronto, Ontario.

John Iazzetta, PharmD, is Co-ordinator, Drug Information, Department of Pharmacy and Division of Pharmacology, Sunnybrook Health Sciences Centre, and Assistant Professor, Faculty of Pharmacy, University of Toronto, Toronto, Ontario.

Shirley Law, Dip Pharm Tech, is a Research Assistant in Quality Control, Department of Pharmacy, Sunnybrook Health Sciences Centre, Toronto, Ontario.

Kristof Biniecki, MD, is Medical Director of Valeo Pharm Inc, Kirkland, Quebec.

\section{Address correspondence to:}

Scott E Walker

Co-ordinator, Research and Quality Control

Department of Pharmacy

Sunnybrook Health Sciences Centre

2075 Bayview Avenue

Toronto ON M4N 3M5

e-mail: scott.walker@sunnybrook.ca 